\title{
The relationship between corporate governance and company performance in concentrated ownership systems: The case of Germany
}

\author{
Ivashkovskaya Irina ${ }^{7}$, Zinkevich Nadezhda $^{8}$
}

This article presents the results of empirical research of the impact of corporate governance system elements (ownership structures and board characteristics) and company performance in the economies with concentrated ownership. Major goals of this study were to develop the empirical methodology allowing for causal relationship between ownership structure elements and corporate performance and to test the methodology using the high-quality data from the developed market with concentrated ownership. The panel data sample of 270 German companies for the period of 2000-2006, originally collected in Sautner \& Villalonga (2009) study and supplemented with additional data by the authors of this article, was used for empirical testing of the hypotheses. Using instrumental variables and simultaneous equations methods to identify causality in the relationship between corporate governance and corporate performance, we found negative impact of insider ownership on performance and positive effect for institutional investors ownership. At the same time, causality in the relationship between board characteristics and company performance cannot be established in the absence of so-called natural experiment, i.e. forced change in board composition due to government policy measures (Black \& Kim 2008), due to the lack of instrumental variables for board characteristics. Two main policy implications of the analysis follow. Firstly, limitations on cross-listing of the companies in foreign stock markets result in lower institutional investors ownership and thus translate in worse companies' performance. Secondly, the equilibrium view of companies' ownership structures, argued for in Demsetz \& Lehn (1985) study, is not supported for concentrated ownership systems with high transaction costs of ownership structures reshuffling (e.g. in case of high capital gains taxes), so governments should adopt any measures, which result in high ownership stakes transferring costs, with caution. The empirical methodology developed in this article may be further used in the research on emerging market data; the study of relationship between corporate governance and company performance under the impact of financial crisis is another promising area of study.

\section{JEL: G32, G34}

Key words: corporate governance, performance, ownership structures, board characteristics, concentrated ownership systems, instrumental variables.

\section{Introduction}

The financial and economic crisis of 2008-2009 made corporate governance one of the most widely discussed aspects of companies' activities. As it was after the dot.com crash and governance scandals of the early 2000 s, corporate governance system is again viewed at the same time as one of the main culprits in the financial crisis and as the power which may facilitate the economic recovery.

\footnotetext{
${ }^{7}$ Professor, Head of Corporate Finance Chair, Head of the Corporate Finance Center, Higher School of Economics, Moscow. E-mail: ivashkovskaya@yandex.ru

${ }^{8}$ Graduate of Strategic Corporate Finance Master program, Higher School of Economics. Consultant at the Business

Valuation department of Ernst \& Young Valuation LLC, Moscow. Email: nadezhda.zinkevich@gmail.com

${ }^{9}$ Nadezhda Zinkevich was the research assistant of Zacharias Sautner at the University of Amsterdam in the academic year 2008-2009 and worked on the data, which formed the basis of this research. The authors are grateful to Professor Sautner for the permission to use the data for this article.
} 
The crisis made evident corporate governance problems of the companies both from developed and from emerging markets. Empire-building ambitions of the management of General Motors and lack of monitoring from shareholders forced the company to undergo restructuring through Chapter 11 of the US Bankruptcy Code, which resulted in dilution of the shareholders' stakes. The speculations of Adolf Merckle, whose family was the controlling shareholder of Ratiopharm and HeidelbergCement, with Volkswagen shares resulted in massive stock market losses and put Ratiopharm and HeidelbergCement on the brink of bankruptcy. Among the recent corporate governance failures in the emerging markets Satyam Computers and RBC Information Systems should be noted. At the beginning of 2009 the CEO of Satyam Computers, fourth largest software exporter in India, announced that he has falsified the company's financial statements for several years for the purpose of inflating net income. In the situation of liquidity squeeze in credit markets the management of Satyam Computers could not obtain refinancing for the loans and had to admit that the company did not have enough cash to continue its activities without external support. The media holding RBC Information System, considered one of the Russian stock market blue chips, announced default on its bonds in March 2009. In summer 2009 controlling shareholders of the company began transfer of the cash-generating assets of the holding to affiliated companies at nominal prices in order to put these assets out of reach of RBC Information Systems creditors and other shareholders. Largest outside shareholders of the holding, Unicredit and Rosbank asset management company, faced the threat of complete impairment of their holdings.

The result of corporate governance scandals of the early 2000s were policy measures in a number of developed economies, including the US (Sarbanes-Oxley act) and the UK (Cadbury Committee recommendations). At present any conclusions about the impact of current financial crisis on corporate governance systems over the world would be premature, but certain changes regarding the top management remuneration system in the US already took place. Anyway, it is now evident that even in the absence of any government interventions corporate governance systems all over the world are undergoing changes mostly due to the reshuffling of companies' ownership structures.

Firstly, due to the restructuring of corporate debts banks are becoming owners of major stakes and sometimes even controlling shareholders of the companies. Although most financial institutions do not have strategic purposes with respect to their newly acquired holdings, they will likely remain major shareholders in the mid-term, until normal business processes in the companies are established and stakes can be resold. Secondly, forced nationalization of "too big to fail" financial institutions and non-financial companies raised the issue of government ownership impact on performance. Although most of the governments, which made nationalization the element of their anti-crisis packages, announced reprivatization plans, this will also take time. For instance, the UK government considers the sale of controlling stakes in RBS and Lloyds feasible only in 20122013.

Thirdly, the US and Western Europe governments announced guidelines on executive compensation packages which imply the increase of the share of noncash component (shares and options) in compensation and the increase of options vesting period - both these measures are expected to result in higher management ownership stakes. Finally, the changes in institutional investors' place in the corporate governance system may follow: further growth of institutional investors activism and increase of the stakes held by institutional investors may be the response to the widespread view of institutional investors as having short-term investment horizon and not being active in corporate governance issues.

At present it is not possible to test the impact of financial crisis on corporate governance systems all over the world and through corporate governance mechanisms - on company performance - due to the evolving nature of corporate governance system and increased volatility of world product and stock markets. However, developing adequate methodology for performing such research in future, using the pre-crisis data, is the important research issue. In the context of the effect on company performance, three corporate governance methods are of most interest because they themselves are formed endogenously: ownership structure, board characteristics and 
executive compensation. It is obvious that for the study of these governance mechanisms simple regression methods (ordinary least squares) do not suffice, because they do not allow ruling out the impact of unobserved factors and the presence of reverse causal relationships, so special methodology is necessary.

For emerging markets the study of ownership concentration, its determinants and its impact on company performance is of particular interest as in these markets ownership concentration remains an important governance mechanism. At the same time, it is not clear whether the merits of ownership concentration in emerging markets exceed the drawbacks. However, the research based on emerging markets data often suffers from low quality of the information used and low number of observations. Therefore, in this article we decided to use the data from developed market, characterized by high ownership concentration (Germany), for the development of the empirical methodology and forming broad conclusions which may as well be relevant for emerging markets.

This article is organized as follows. Section 2 presents the overview of existing research of the link between corporate governance elements (ownership structures and board characteristics) and company performance, done both on developed markets data and on emerging markets data. Special attention is given to the methods of econometric analysis used in order to deal with endogeneity and reverse causality problems. Section 3 describes the data used in the study; in Section 4 key hypotheses with respect to ownership structures determinants and to the impact of corporate governance elements on performance are formulated. In Section 5 the problems of endogeneity and reverse causality are discussed in more detail, and empirical methodology used to deal with them is outlined. Section 6 presents the results of empirical analysis and provides their interpretation; Section 7 specifies major policy implications of the research and concludes.

\section{Research overview}

Most studies of the links between company performance, on one side, and ownership structure and board characteristics, on the other side, have the same framework. Regression of the following form is estimated using either ordinary least squares method (OLS) or more complicated econometric techniques such as fixed effects and instrumental variables:

$$
\operatorname{Perf}_{i t}=a+O w n_{i t} * b+\text { Board }_{i t} * c+X_{i t} d+\varepsilon_{i t}, \text { where }
$$

Perf is one of the proxies for company performance (Tobin's Q and ROA are used as proxies most often);

Own is the vector of the company's ownership structure characteristics (ownership concentration and owner type measures);

Board is the vector of board characteristics (board size, percentage of independent directors etc.);

$X$ is the vector of control variables (profitability, leverage, liquidity, sales growth, company age, dummy variables for industries etc.)

The number of studies using alternative methodologies is very limited: e.g. Farinos, Garcia \& Ibanez (2006) use event study in order to study the link between ownership structure and performance, and Rosenstein \& Wyatt $(1990,1997)$ apply the same approach for establishing causal relationship between the percentage of independent directors in the board and performance.

The theoretical discussion of the ownership structure impact on agency costs within a corporation and, as a result, on company performance was opened by Berle \& Means (1932). Since then large number of empirical studies was performed, both on developed markets and emerging markets (primarily the countries of South-East Asia) data. Ownership structure by definition is a vector of variables (ownership concentration, different owner types), and existing studies addressed each component of this vector. Ownership concentration was approximated either by HefindahlHirshman index calculated based on blockholders' stakes or by the sum of all blockholders' stakes; owner types studies included insiders (management and board members), owner families, institutional investors and the government.

Table 1 below presents the summary of the studies of the link between company performance 
and ownership structures, performed on developed markets data. Is should be noted that not all studies use relevant econometric techniques to control for the endogeneity of ownership structures, so their results may be questioned. In general, for many developed markets samples (in particular, for the US and the UK data) the so-called "equilibrium concept" of ownership structure is supported. Formulated at the first time by Demsetz \& Lehn (1985), this concept implies that ownership is always determined endogenously in order to maximize the company's performance, because this is beneficial for all owners. There should be no systematic relationship between observed ownership structures and performance, because the presence of such relationship would imply that there is potential for performance improvement as a result of ownership structure reshuffling. At the same time, for the developed market with concentrated ownership (Germany) the equilibrium concept is not supported, and specific investor types (insiders, owner families) may positively affect performance. Based on the result of two recent studies (Gianetti \& Laeven 2008, Ferreira \& Matos 2008), the presence of institutional investors among blockholders may improve performance, but this relationship is subject to the type of institutional investor.

Table 1

Summary of major studies on the relationship between company performance and ownership structures (developed markets)

\begin{tabular}{|c|c|c|c|c|c|}
\hline \begin{tabular}{|c|} 
Authors, \\
year of \\
publication
\end{tabular} & Market & Owner types & $\begin{array}{c}\text { Sample } \\
\text { description }\end{array}$ & Main results & $\begin{array}{l}\text { Methods to deal with } \\
\text { endogeneity and reverse } \\
\text { causality }\end{array}$ \\
\hline $\begin{array}{c}\text { Demsetz \& } \\
\text { Lehn (1985) }\end{array}$ & US & Blockholders & $\begin{array}{l}\text { Cross-section } \\
\text { sample, } 511 \\
\text { companies, } \\
\text { average of } \\
\text { variables for } \\
1976-1980\end{array}$ & $\begin{array}{l}\text { No relationship between } \\
\text { ownership concentration } \\
\text { (presence of blockholders) } \\
\text { and company performance }\end{array}$ & $\begin{array}{l}\text { 2SLS with instrumental } \\
\text { variables; instruments for } \\
\text { ownership concentration - } \\
\text { size, profit volatility, } \\
\text { dummy variables for } \\
\text { regulated industries and } \\
\text { industries with amenity } \\
\text { potential }\end{array}$ \\
\hline $\begin{array}{l}\text { Morck, } \\
\text { Shleifer \& } \\
\text { Vishny } \\
(1988)\end{array}$ & US & $\begin{array}{c}\text { Insiders } \\
\text { (managers) }\end{array}$ & $\begin{array}{l}\text { Cross-section } \\
\text { sample, } 371 \\
\text { companies, } \\
\text { data for } 1980\end{array}$ & $\begin{array}{c}\text { Piecewise linear regression. } \\
\text { Positive impact of ownership } \\
\text { on performance (Tobin's Q) } \\
\text { for ownership stake intervals } \\
0 \%-5 \% \text { and above } 20 \% \text {; } \\
\text { negative impact for the } \\
\text { interval between } 5 \% \text { and } \\
20 \% \text {. }\end{array}$ & $\begin{array}{l}\text { OLS. No methods to control } \\
\text { for endogeneity and reverse } \\
\text { causality }\end{array}$ \\
\hline $\begin{array}{c}\text { McConnell } \\
\text { \& Servaes } \\
(1990)\end{array}$ & US & $\begin{array}{c}\text { Blockholders; } \\
\text { Insiders } \\
\text { (managers) }\end{array}$ & $\begin{array}{l}\text { Cross-section } \\
\text { sample, } 1,000 \\
\text { companies, } \\
\text { data for } 1976 \\
\text { and } 1980\end{array}$ & $\begin{array}{c}\text { Quadratic regression. } \\
\text { Positive impact on } \\
\text { performance for managers' } \\
\text { ownership stakes below 30- } \\
\text { 40\%; negative relationship } \\
\text { for higher stakes. Total } \\
\text { blockholders ownership does } \\
\text { not impact performance. }\end{array}$ & $\begin{array}{l}\text { OLS. No methods to control } \\
\text { for endogeneity and reverse } \\
\text { causality }\end{array}$ \\
\hline $\begin{array}{l}\text { Himmelberg } \\
\text {, Hubbard \& } \\
\text { Palia (1999) }\end{array}$ & US & $\begin{array}{c}\text { Insiders } \\
\text { (managers and } \\
\text { board } \\
\text { members). }\end{array}$ & $\begin{array}{c}\text { Panel data, } \\
\text { about } 400 \\
\text { companies, } \\
1982-1992\end{array}$ & $\begin{array}{c}\text { Reverse U-shared } \\
\text { relationship between } \\
\text { managers' ownership stake } \\
\text { and performance, which } \\
\text { persists when instrumental } \\
\text { variables are introduced to } \\
\text { control for endogeneity and } \\
\text { reverse causality. }\end{array}$ & $\begin{array}{l}\text { Fixed effects regression to } \\
\text { control for unobserved } \\
\text { heterogeneity. 2SLS with } \\
\text { instrumental variables for } \\
\text { ownership: firm size and } \\
\text { specific risk (CAPM model } \\
\text { residual). }\end{array}$ \\
\hline $\begin{array}{c}\text { Demsetz \& } \\
\text { Villalonga } \\
(2001)\end{array}$ & US & $\begin{array}{c}\text { Blockholders; } \\
\text { Insiders } \\
\text { (managers) }\end{array}$ & $\begin{array}{l}\text { Cross-section } \\
\text { sample, } 223 \\
\text { companies } \\
\text { randomly } \\
\text { chosen from } \\
\text { Demsetz \& }\end{array}$ & $\begin{array}{l}\text { No impact of ownership } \\
\text { structure on performance. At } \\
\text { the same time, the stake } \\
\text { owned by insiders negatively } \\
\text { depends on Tobins'Q. }\end{array}$ & $\begin{array}{l}\text {.2SLS with instrumental } \\
\text { variables for ownership: } \\
\text { firm size, market risk (beta } \\
\text { coefficient) and specific risk } \\
\text { (CAPM model residual). }\end{array}$ \\
\hline
\end{tabular}




\begin{tabular}{|c|c|c|c|c|c|}
\hline $\begin{array}{c}\text { Authors, } \\
\text { year of } \\
\text { publication }\end{array}$ & Market & Owner types & $\begin{array}{c}\text { Sample } \\
\text { description }\end{array}$ & Main results & $\begin{array}{c}\text { Methods to deal with } \\
\text { endogeneity and reverse } \\
\text { causality }\end{array}$ \\
\hline & & & $\begin{array}{c}\text { Lehn (1985) } \\
\text { sample }\end{array}$ & & \\
\hline $\begin{array}{l}\text { Villalonga } \\
\text { \& Amit } \\
\text { (2006) }\end{array}$ & US & $\begin{array}{l}\text { Owner } \\
\text { families }\end{array}$ & $\begin{array}{l}\text { Fortune } 500 \\
\text { companies for } \\
\text { years } 1994- \\
2000(508 \\
\text { different } \\
\text { companies in } \\
\text { total) }\end{array}$ & $\begin{array}{c}\text { The impact of family block } \\
\text { ownership on performance is } \\
\text { positive if company founder } \\
\text { is the CEO. In "second } \\
\text { generation" firms (managed } \\
\text { not by the family) the effect } \\
\text { of family ownership on } \\
\text { Tobin's Q is negative. }\end{array}$ & $\begin{array}{c}\text { Fixed-effects estimation and } \\
\text { treatment effects regression } \\
\text { (variation of instrumental } \\
\text { variables method for binary } \\
\text { ownership variables). } \\
\text { Instruments: specific risk } \\
\text { (CAPM model residual) and } \\
\text { lagged Tobin's Q. } \\
\end{array}$ \\
\hline $\begin{array}{l}\text { Erhardt, } \\
\text { Nowak \& } \\
\text { Weber } \\
(2006)\end{array}$ & Germany & $\begin{array}{l}\text { Owner } \\
\text { families }\end{array}$ & $\begin{array}{l}124 \text { companies, } \\
\text { including } 62 \\
\text { companies with } \\
\text { family } \\
\text { ownership; } \\
\text { panel data for } \\
1993-2003\end{array}$ & $\begin{array}{c}\text { Positive relationship between } \\
\text { performance (ROA) and } \\
\text { presence of a family among } \\
\text { blockholders }\end{array}$ & $\begin{array}{l}\text { Treatment effects } \\
\text { regression; instruments for } \\
\text { ownership: company age } \\
\text { and its industry }\end{array}$ \\
\hline $\begin{array}{l}\text { Thomsen } \\
\text { (2004) }\end{array}$ & $\begin{array}{c}\text { US, UK, } \\
\text { continental } \\
\text { Europe }\end{array}$ & Blockholders & $\begin{array}{l}990 \text { companies, } \\
\text { panel data for } \\
1989-1998 .\end{array}$ & $\begin{array}{c}\text { No relationship between } \\
\text { ownership concentration and } \\
\text { performance for the UK and } \\
\text { the US. Negative relationship } \\
\text { for continental Europe, } \\
\text { which may be attributed to } \\
\text { higher reinvestment rates and } \\
\text { lower dividends of } \\
\text { companies with concentrated } \\
\text { ownership }\end{array}$ & $\begin{array}{l}\text { Fixed-effects regression, } \\
\text { estimated by generalized } \\
\text { method of moments } \\
\text { (GMM). }\end{array}$ \\
\hline $\begin{array}{l}\text { Kaserer, } \\
\text { Moldenhaue } \\
\text { r (2007) }\end{array}$ & Germany & $\begin{array}{c}\text { Blockholders; } \\
\text { Insiders } \\
\text { (managers and } \\
\text { board } \\
\text { members) and } \\
\text { their families }\end{array}$ & $\begin{array}{l}\text { About } 230 \\
\text { firms included } \\
\text { in CDAX } \\
\text { index, panel } \\
\text { data for } 1998- \\
2003\end{array}$ & $\begin{array}{c}\text { Positive relationship between } \\
\text { performance and insider } \\
\text { ownership, which persists in } \\
\text { instrumental variables } \\
\text { estimation. }\end{array}$ & $\begin{array}{l}\text { 2SLS with instrumental } \\
\text { variables for ownership: } \\
\text { number of management } \\
\text { board members, dummy for } \\
\text { existence of non-voting } \\
\text { shares, ratio of intangibles } \\
\text { to total assets }\end{array}$ \\
\hline $\begin{array}{l}\text { Ferreira \& } \\
\text { Matos } \\
(2008)\end{array}$ & \begin{tabular}{|c|}
40 \\
countries \\
(excluding \\
the US), \\
developed \\
and \\
emerging \\
markets \\
\end{tabular} & $\begin{array}{c}\text { Institutional } \\
\text { investors } \\
\text { (domestic and } \\
\text { foreign, } \\
\text { independent } \\
\text { and company- } \\
\text { affiliated) }\end{array}$ & $\begin{array}{l}\text { More than } \\
35,000 \\
\text { companies, } \\
\text { panel data for } \\
\text { 2000-2005 } \\
\text { period }\end{array}$ & \begin{tabular}{|} 
Positive relationship between \\
performance and ownership \\
stake of foreign and \\
independent institutional \\
investors; higher ownership \\
stake of affiliated \\
institutional investors \\
decreases performance
\end{tabular} & $\begin{array}{c}\text { Simultaneous equations for } \\
\text { Tobin's Q and institutional } \\
\text { investors ownership. } \\
\text { Instruments for ownership: } \\
\text { company's presence in } \\
\text { MSCI World index, cross- } \\
\text { listing in the US, dividend } \\
\text { yield, specific risk (CAPM } \\
\text { model residual) } \\
\end{array}$ \\
\hline $\begin{array}{c}\text { Giannetti \& } \\
\text { Laeven } \\
(2008)\end{array}$ & Sweden & $\begin{array}{l}\text { Institutional } \\
\text { investors } \\
\text { (pension } \\
\text { funds) }\end{array}$ & $\begin{array}{l}\text { Panel data for } \\
1999-2005, \text { in } \\
\text { total about } \\
1,600 \\
\text { observations }\end{array}$ & $\begin{array}{c}\text { Positive relationship between } \\
\text { performance (Tobin's) and } \\
\text { ownership stake of } \\
\text { independent pension funds }\end{array}$ & $\begin{array}{c}\text { 2SLS with instrumental } \\
\text { variables. Instruments for } \\
\text { pension funds ownership: } \\
\text { presence of the company in } \\
\text { main stock market index, } \\
\text { the share of company's } \\
\text { stock in mutual funds } \\
\text { holdings }\end{array}$ \\
\hline $\begin{array}{c}\text { Becker, } \\
\text { Cronquist \& } \\
\text { Fahlenbrach } \\
\quad(2009)\end{array}$ & US & \begin{tabular}{|c|} 
Individual \\
blockholders \\
(independent \\
of \\
management)
\end{tabular} & $\begin{array}{l}\text { Panel data for } \\
1996-2001 \\
\text { (over } 1800 \\
\text { firms) }\end{array}$ & $\begin{array}{c}\text { Presence of individual } \\
\text { independent blockholders } \\
\text { positively affects } \\
\text { performance (ROA and } \\
\text { ROS); this may be due to } \\
\text { preventing unprofitable } \\
\text { investments by management }\end{array}$ & $\begin{array}{c}\text { 2SLS with instrumental for } \\
\text { the presence of individual } \\
\text { blockholders присутствия } \\
\text { индивидуального } \\
\text { блокхолдера: density of } \\
\text { high wealth individuals in } \\
\text { the state of incorporation of } \\
\text { the company }\end{array}$ \\
\hline
\end{tabular}


Table 2 below presents the summary of the studies of the link between company performance and ownership structures, performed on emerging markets data. It should be noted that many of these studies use productivity as performance measure instead of Tobin's Q and ROA, which is due to the low of emerging markets stocks and the unreliability of accounting data with respect to net income. Labour productivity, calculated by dividing company revenue by the personnel headcount thus provides the measure less subject to manipulations.

Special attention is given to the studies which are based on the data from Russian market. The first group of them (Earle 1998, Kuznetsov \& Muravyev 2000, Muravyev 2002) focuses primarily on the effect of privatization on company performance by studying the link between government and non-government owner types and performance. Positive impact of privatization on performance is identified, but it should be noted that this may be the result of reverse causality: private investors could have agreed to acquire only the stakes in better-performing companies, leaving worse-performing companies with government ownership. The focus of the second group of studies is on the relationship between the level of ownership concentration and performance and possible nonlinearity of this relationship. Guriev et. al. (2003) and Dolgopyatova (2004) found inverse U-shaped relationship between ownership concentration and performance, which is similar to the results obtained by Morck, Shleifer \& Vishny (1988) and McConnell \& Servaes (1990) for the US market. Radygin \& Entov (2001) found positive relationship between ownership concentration and performance and supported the conclusion of Earle (1998) with respect to privatization: the companies where government stakes were sold to private investors demonstrated better performance, and the earlier privatization was conducted, the better was the performance. The third group of studies (Bokov \& Vernikov 2008, Ivashkovskaya \& Stepanova 2009, Pirogov \& Bobryshev 2009) is based on Russian market data for the period prior to the financial crisis. These studies established positive relationship between the insiders' ownership stake and company performance.

Table 2

Summary of major studies on the relationship between company performance and ownership structures (emerging markets)

\begin{tabular}{|c|c|c|c|c|c|}
\hline $\begin{array}{l}\text { Authors, year } \\
\text { of publication }\end{array}$ & Market & Owner types & $\begin{array}{c}\text { Sample } \\
\text { description }\end{array}$ & Main results & $\begin{array}{l}\text { Methods to deal } \\
\text { with endogeneity } \\
\text { and reverse } \\
\text { causality }\end{array}$ \\
\hline Lins (2003) & $\begin{array}{c}18 \\
\text { emerging } \\
\text { markets } \\
\text { (not } \\
\text { including } \\
\text { Russia) }\end{array}$ & $\begin{array}{l}\text { Outside } \\
\text { blockholders; } \\
\text { insiders } \\
\text { (managers) }\end{array}$ & $\begin{array}{l}\text { 1,433 companies, } \\
\text { cross-section data } \\
\text { for } 1995\end{array}$ & $\begin{array}{l}\text { Performance is negatively } \\
\text { related to the stake owned by } \\
\text { the management and positively } \\
\text { by the stake owned by outside } \\
\text { blockholders. Results persist in } \\
\text { the IV estimation, but statistical } \\
\text { power of the instruments is low }\end{array}$ & $\begin{array}{c}\text { 2SLS with } \\
\text { instrumental } \\
\text { variables for } \\
\text { ownership: } \\
\text { company size, beta } \\
\text { and Jensen's alpha }\end{array}$ \\
\hline $\begin{array}{c}\text { Kocenda \& } \\
\text { Svejnar (2002) }\end{array}$ & $\begin{array}{c}\text { Czech } \\
\text { Republic }\end{array}$ & $\begin{array}{c}\text { Top } \\
\text { blockholder } \\
\text { ownership } \\
\text { stake, } \\
\text { government } \\
\text { ownership } \\
\text { ("golden } \\
\text { share"), } \\
\text { foreign } \\
\text { ownership }\end{array}$ & $\begin{array}{c}\text { About 1,200 } \\
\text { companies quoted } \\
\text { in Prague Stock } \\
\text { Exchange in 1996- } \\
1999 \text { (panel data) }\end{array}$ & $\begin{array}{c}\text { Companies with dispersed } \\
\text { ownership demonstrate the best } \\
\text { performance. Presence of } \\
\text { government ownership affects } \\
\text { performance negatively; } \\
\text { foreign investors presence - } \\
\text { positively }\end{array}$ & $\begin{array}{l}\text { Regression in } \\
\text { percentage } \\
\text { differences, which } \\
\text { allows ruling out } \\
\text { the impact of } \\
\text { unobserved } \\
\text { endogeous } \\
\text { variables } \\
\text { (equivalent to } \\
\text { fixed-effects } \\
\text { model) } \\
\end{array}$ \\
\hline $\begin{array}{c}\text { Driffield, } \\
\text { Mahambare, Pal } \\
(2006)\end{array}$ & $\begin{array}{c}\text { Indonesia, } \\
\text { Malaysia } \\
\text { South } \\
\text { Korea, } \\
\text { Thailand }\end{array}$ & $\begin{array}{c}\text { Blockholders, } \\
\text { owner families }\end{array}$ & \begin{tabular}{c|} 
Panel data for \\
1994-1998, 1,750 \\
companies in total
\end{tabular} & $\begin{array}{l}\text { Positive relationship between } \\
\text { Tobin's Q and ownership } \\
\text { concentration (sum of all } \\
\text { blockholdings). }\end{array}$ & $\begin{array}{l}\text { OLS. No methods } \\
\text { to control for } \\
\text { endogeneity and } \\
\text { reverse causality }\end{array}$ \\
\hline Earle (1998) & Russia & $\begin{array}{c}\text { Non- } \\
\text { government }\end{array}$ & $\begin{array}{l}383 \text { companies, } \\
\text { cross-section for }\end{array}$ & $\begin{array}{c}\text { Positive effect on non- } \\
\text { government ownership on }\end{array}$ & $\begin{array}{l}\text { 2SLS with } \\
\text { instrumental }\end{array}$ \\
\hline
\end{tabular}




\begin{tabular}{|c|c|c|c|c|c|}
\hline $\begin{array}{l}\text { Authors, year } \\
\text { of publication }\end{array}$ & Market & Owner types & $\begin{array}{c}\text { Sample } \\
\text { description }\end{array}$ & Main results & $\begin{array}{l}\text { Methods to deal } \\
\text { with endogeneity } \\
\text { and reverse } \\
\text { causality }\end{array}$ \\
\hline & & \begin{tabular}{|l|} 
ownership; \\
insiders; \\
outside \\
investors, \\
independent of \\
management
\end{tabular} & 1994 & $\begin{array}{l}\text { performance (productivity), } \\
\text { attributed mostly due to the } \\
\text { presence of outside investors }\end{array}$ & $\begin{array}{l}\text { variables for } \\
\text { ownership: } \\
\text { prices control, } \\
\text { export orientation } \\
\text { of the business, } \\
\text { government } \\
\text { subsidies etc. }\end{array}$ \\
\hline $\begin{array}{l}\text { Kuznetsov, } \\
\text { Muravyev } \\
(2000)\end{array}$ & Russia & $\begin{array}{c}\text { Blockholders, } \\
\text { insiders } \\
\text { (management), } \\
\text { Russian } \\
\text { outside } \\
\text { investors, } \\
\text { foreign } \\
\text { ownership }\end{array}$ & $\begin{array}{l}101 \text { companies, } \\
\text { panel data for } \\
1995-1997\end{array}$ & $\begin{array}{c}\text { Negative relationship between } \\
\text { performance and ownership } \\
\text { concentration Presence of } \\
\text { foreign blockholders positively } \\
\text { affects performance. }\end{array}$ & $\begin{array}{l}\text { 2SLS with } \\
\text { instrumental } \\
\text { variables for } \\
\text { ownership: } \\
\text { privatization } \\
\text { characteristics, } \\
\text { social-economic } \\
\text { situation in the } \\
\text { region of the } \\
\text { company's } \\
\text { functioning, } \\
\text { financial } \\
\text { characteristics of } \\
\text { the companies' } \\
\text { industries }\end{array}$ \\
\hline $\begin{array}{l}\text { Muravyev } \\
(2002)\end{array}$ & Russia & Government & $\begin{array}{c}\text { 4,400 companies, } \\
\text { cross-sectional data } \\
(2001)\end{array}$ & $\begin{array}{c}\text { Negative relationship between } \\
\text { performance measures and } \\
\text { presence of the government } \\
\text { among blockholders. }\end{array}$ & $\begin{array}{l}\text { OLS with lagged } \\
\text { dependent variable } \\
\text { as regressor. No } \\
\text { control for } \\
\text { endogeneity and } \\
\text { reverse causality: } \\
\text { government could } \\
\text { have chosen to } \\
\text { privatize only } \\
\text { better-performing } \\
\text { companies }\end{array}$ \\
\hline $\begin{array}{l}\text { Bokov, } \\
\text { Vernikov } \\
(2008)\end{array}$ & Russia & $\begin{array}{l}\text { Controlling } \\
\text { shareholders }\end{array}$ & $\begin{array}{c}25 \text { IPO transaction } \\
\text { of Russian banks } \\
(2005-2008)\end{array}$ & \begin{tabular}{|c|} 
Companies with higher \\
ownership concentration got \\
higher valuations in IPO, which \\
may proxy for better expected \\
performance
\end{tabular} & $\begin{array}{l}\text { OLS. No methods } \\
\text { to control for } \\
\text { endogeneity and } \\
\text { reverse causality }\end{array}$ \\
\hline $\begin{array}{c}\text { Ivashkovskaya, } \\
\text { Stepanova } \\
(2009)\end{array}$ & $\begin{array}{l}\text { Russia, } \\
\text { Central and } \\
\text { Eastern } \\
\text { Europe, } \\
\text { Western } \\
\text { Europe } \\
\end{array}$ & $\begin{array}{c}\text { Insiders, } \\
\text { government }\end{array}$ & $\begin{array}{c}178 \text { companies in } \\
\text { total, cross-section } \\
\text { data for } 2007\end{array}$ & $\begin{array}{l}\text { Positive impact of insiders } \\
\text { presence on performance; } \\
\text { impact of government } \\
\text { performance depends on the } \\
\text { country }\end{array}$ & $\begin{array}{l}\text { OLS. No methods } \\
\text { to control for } \\
\text { endogeneity and } \\
\text { reverse causality }\end{array}$ \\
\hline $\begin{array}{l}\text { Pirogov, } \\
\text { Bobryshev } \\
(2009)\end{array}$ & $\begin{array}{l}\text { Russia, } \\
\text { Eastern } \\
\text { Europe }\end{array}$ & $\begin{array}{l}\text { Management, } \\
\text { government, } \\
\text { independent } \\
\text { shareholders } \\
\text { (not affiliated } \\
\text { with } \\
\text { management) }\end{array}$ & $\begin{array}{c}131 \text { companies in } \\
\text { total, cross-section } \\
\text { data for } 2007\end{array}$ & $\begin{array}{c}\text { Positive impact of management } \\
\text { ownership stake on } \\
\text { performance. Companies with } \\
\text { dispersed ownership (larger } \\
\text { number of shareholders) have } \\
\text { worse performance. }\end{array}$ & $\begin{array}{l}\text { OLS. No methods } \\
\text { to control for } \\
\text { endogeneity and } \\
\text { reverse causality }\end{array}$ \\
\hline
\end{tabular}

Board characteristics, the impact of which is most often studied, are board size and the percentage of outside directors in the board. Outside directors are defined as individuals who are not the employees of the company or any affiliated companies, do not render consulting services to the company's management, do not receive any income from the company and are not relatives of the company's executives. Some studies also examine the impact of cross-board representation, which result in one director holding the seats in several boards of directors, on performance (Fich 
\& Shivdasani 2006).

Existing studies find consistent inverse relationship between board size and company performance (Yermack 1996, Eisenberg et. al. 1998), which is attributed to the fact that in large boards agency conflicts emerge within the board itself, so actions of the board may harm the shareholders instead of protecting them. However, developed markets evidence on the link between the percentage of outside directors and performance is not conclusive: most of the studies find no relationship between these variables (MacAvoy et al. 1983, Mehran 1995, Klein 1998, Hermalin and Weisbach 1991 и Bhagat and Black 2000), but this may be due to the effect of endogeneity and reverse causality. If firms increase the percentage of outside directors in response to poor performance, which is then improved by value-maximizing actions of these directors, no systematic relationship may be observed in result. Dahya \& McConnell (2007) make an attempt to establish causal relationships between the percentage of outside directors and performance by using the "natural experiment" setting (Cadbury Committee recommendations in the UK). However, as Cadbury Committee recommendations required only three outside directors in the board (not the majority) and the compliance was voluntary, the causal link cannot be considered firmly established.

By applying event study method (study of abnormal stock returns around board composition change announcements), Rosenstein \& Wyatt $(1990,1997)$ show that addition of outside directors to the board results in positive abnormal returns; however, they are not able to distinguish the effect from the effect of other announcements (e.g. addition of an executive director to the board).

Among emerging markets studies of the link between percentage of outside directors and company performance five studies should be mentioned. Black, Jang \& Kim (2006) and Choi, Park \& Yoo (2007), using data on South Korean firms, find no relationship between the aforementioned variables. Yeh \& Woidtke (2005), studying the data on Taiwanese firms, show that lower performance is associated with higher percentage of insiders (directors affiliated with the controlling family) in the board. Ivashkovskaya \& Stepanova (2008) find positive relationship between the presence of outside directors in the board and performance, but the percentage of outside directors is not related to performance, so board composition with minimum number of outside directors may be optimal. However, all studies mentioned do not identify causality in the relationship between board characteristics and performance.

Black \& Kim (2008) study is different as it uses the "natural experiment" setting in South Korea. In 1999 the law, requiring large corporate to have at least half outside directors in the board, became effective in this country. Using the fact that small firms were not subject to this policy measure, Black \& Kim perform differences-in-differences analysis and show that performance improvement after the reform was more significant for large firms than for small ones. This effect is attributed to positive impact of the presence of outside directors in the board on company performance. It should be noted that due to the lack of suitable instrumental variables for the percentage of outside directors in the board the use such "natural experiment" setting is the only way to establish causality between this governance variable and performance.

\section{Data description}

In this article the sample of companies from developed market with concentrated ownership (Germany) was used for empirical testing of the hypotheses (described below in the "Main hypotheses and models") section. This sample was initially constructed in the Sautner \& Villalonga (2009) research and then supplemented by the authors of this article with some additional data.

This sample (panel data, years 2000-2006) was used in research for three main reasons. Firstly, high quality of the data and large company size increase the robustness of the results and allow such econometric techniques as fixed effects model to be used. Secondly, as corporate governance system in Germany is quite similar to those in emerging markets (high ownership concentration, insiders are predominant owners), certain results of this research may be applicable to emerging markets as well. Finally, using the data on German firms for 2000-2006 allows taking 
advantage of a kind of "natural experiment" in the form of tax reform. Since 1 January 2002 zero capital gains tax rate on the holdings kept for more than a year was set, instead of $50 \%$ capital gains tax effective before, which decreased transaction costs of ownership structures reshuffling. This created time-variation in the ownership data, which is often not present in the samples used for testing the link between ownership and performance.

The basis for the sample was formed by taking all firms quoted in the Frankfurt Stock Exchange in 2000 and included in one of the four German stock market indices: CDAX, TechDAX, MDAX or SDAX). Financial institutions and real estate forms (US SIC codes 6000 and 6999) were excluded from the sample. For all remaining companies financial data was collected from the Worldscope database for the period 2000-2006. Corporate governance data (ownership structure and board characteristics) was collected directly from the companies' annual reports or 20-F forms submitted to the SEC.

For the purpose of this research, the sample, constructed for Sautner \& Villalonga (2009) study and described above, was supplemented by stock market volatility data. We calculated the measure of market risk (beta coefficient) and the measure of specific risk (standard error of the residual in the CAPM model) based on Bloomberg data. All these actions resulted in a sample of 268 companies, 1,870 observations in total.

The sample contains five blocks of variables: performance measures, ownership structure characteristics, board characteristics, ownership structure instruments and control variables. They are described in Table 3 below.

Table 3

Description of the variables used in the research

\begin{tabular}{|c|c|c|}
\hline Variable & Definition & Source \\
\hline \multicolumn{3}{|c|}{ 1. Performance characteristics } \\
\hline Q & $\begin{array}{l}\text { Tobin's Q. The market value of assets divided by the book value } \\
\text { of assets. The market value of assets equals the book value of } \\
\text { assets plus the market value of equity less the book value of } \\
\text { equity. }\end{array}$ & Worldscope \\
\hline $\log q$ & $\begin{array}{l}\text { Variable equal to } \log (\mathrm{Q}) \text {, constructed in order to make the } \\
\text { distribution of the variable closer to normal }\end{array}$ & Self-constructed \\
\hline oneq & Variable equal to $(-1 / \mathrm{Q})$ & Self-constructed \\
\hline $\mathrm{ROA}$ & $\begin{array}{l}\text { Return on assets: earnings before interest and taxes (EBIT) } \\
\text { divided by total assets. }\end{array}$ & Worldscope \\
\hline \multicolumn{3}{|c|}{ 2. Ownership structure characteristics } \\
\hline block_ownership & $\begin{array}{l}\text { The sum of the shareholdings of all owners that own more than } \\
5 \% \text { of a firm. }\end{array}$ & \multirow{7}{*}{$\begin{array}{l}\text { Hand-collected } \\
\text { from Annual } \\
\text { Reports/Form 20-F }\end{array}$} \\
\hline ownership_concentration & $\begin{array}{l}\text { The Herfindahl index of ownership concentration. It is calculated } \\
\text { as the sum of the squared ownership stakes of all shareholders that } \\
\text { own more than } 5 \% \text { of a firm }\end{array}$ & \\
\hline top_blockholder & $\begin{array}{l}\text { The size of the stake of the firm's largest shareholder (if the } \\
\text { shareholder owns more than } 5 \% \text { ). }\end{array}$ & \\
\hline Financials & $\begin{array}{l}\text { The sum of the shareholdings of financial institutions (banks and } \\
\text { insurance companies) that own more than } 5 \% \text { of a firm. }\end{array}$ & \\
\hline Institutional & $\begin{array}{l}\text { The sum of the shareholdings of institutional investors that own } \\
\text { more than } 5 \% \text { of a firm. }\end{array}$ & \\
\hline Government & $\begin{array}{l}\text { The sum of the shareholdings of the government (federal and } \\
\text { regional authorities) that own more than } 5 \% \text { of a firm. }\end{array}$ & \\
\hline Insider & $\begin{array}{l}\text { The sum of the shareholdings of insiders (management, board } \\
\text { members, family owners) that own more than } 5 \% \text { of a firm. }\end{array}$ & \\
\hline \multicolumn{3}{|l|}{ 3. Board characteristics } \\
\hline outside_directors & $\begin{array}{l}\text { Percentage of directors on the supervisory board who are } \\
\text { outsiders. Outsiders are directors that are neither current nor } \\
\text { former executives/employees of the company. Union activists are } \\
\text { not categorized as outsiders. }\end{array}$ & $\begin{array}{l}\text { Hand-collected } \\
\text { from Annual } \\
\text { Reports/Form 20-F }\end{array}$ \\
\hline size_supervisory_board & $\begin{array}{l}\text { Number of directors in the company's supervisory board (in } \\
\text { Germany boards are two-tied, and the first tier, management } \\
\text { board, is comprised of executives and participates in the day-to- }\end{array}$ & $\begin{array}{l}\text { Hand-collected } \\
\text { from Annual } \\
\text { Reports/Form 20-F }\end{array}$ \\
\hline
\end{tabular}




\begin{tabular}{|c|c|c|}
\hline Variable & Definition & Source \\
\hline & day operations of the company). & \\
\hline mandates_chairman & $\begin{array}{l}\text { Number of additional firms where the chairman of the supervisory } \\
\text { board also serves on the supervisory or executive board. }\end{array}$ & $\begin{array}{l}\text { Hand-collected } \\
\text { from Annual } \\
\text { Reports/Form 20-F }\end{array}$ \\
\hline $\begin{array}{l}\text { chairman_- } \\
\text { former_executive }\end{array}$ & $\begin{array}{l}\text { Dummy that is set equal to one if the chairman of the supervisory } \\
\text { board is a former executive board member of the firm. }\end{array}$ & $\begin{array}{l}\text { Hand-collected } \\
\text { from Annual } \\
\text { Reports/Form 20-F }\end{array}$ \\
\hline \multicolumn{3}{|c|}{ 4. Instrumental variables for ownership structure } \\
\hline Firm size & Logarithm of the book value of the company's total assets. & Worldscope \\
\hline Beta & $\begin{array}{l}\text { Beta estimated from regression of the company's stock returns on } \\
\text { CDAX index returns (two-year period prior to the date of } \\
\text { observation) }\end{array}$ & Bloomberg \\
\hline Specrisk & $\begin{array}{l}\text { Standard error of residual in the CAPM model, from which beta } \\
\text { was derived }\end{array}$ & Bloomberg \\
\hline Dummy_US & $\begin{array}{l}\text { Dummy variable equalling one if the company has cross-listing in } \\
\text { the US and zero otherwise }\end{array}$ & Worldscope \\
\hline Dummy_CDAX & $\begin{array}{l}\text { Dummy variable equalling one if the company is included in the } \\
\text { CDAX index and zero otherwise }\end{array}$ & Worldscope \\
\hline Dummy_Post2001 & $\begin{array}{l}\text { Dummy variable equalling one for the observations after the tax } \\
\text { reform (years 2002-2006) and zero for the before-reform } \\
\text { observations }\end{array}$ & Self-constructed \\
\hline \multicolumn{3}{|l|}{ 5. Control variables } \\
\hline Leverage & The company's total debt divided by total assets. & Worldscope \\
\hline Liquidity & $\begin{array}{l}\text { Absolute liquidity coefficient: value of cash and marketable } \\
\text { securities divided by total assets. }\end{array}$ & Worldscope \\
\hline Age & $\begin{array}{l}\text { Company age, i.e. the period since the company's foundation and } \\
\text { the date of the observation }\end{array}$ & Worldscope \\
\hline Sales_growth & $\begin{array}{l}\text { The company's sales growth rate in the year of the observation } \\
\text { compared to previous year }\end{array}$ & Worldscope \\
\hline
\end{tabular}

Summary tables including the sample characteristics and correlations analysis are shown in the Appendix to this article. Analysis of the sample characteristics yielded the following main results:

1. The companies from pharmaceuticals, engineering and technology industries prevail in the sample, which correctly represents the overall structure of German economy.

2. There is substantial industry variation in Tobin's Q and ROA, on one side, and ownership concentration, on the other side. Therefore, in addition to company characteristics such as leverage, liquidity, company age industry dummies should be included in regressions as controls.

3. German companies are characterized by high ownership concentration: average stake of top blockholder is $31.5 \%$, and average sum of all blockholders' stakes is $41.0 \%$. This is in line with Faccio \& Lang (2000) study, which was the first to draw attention to large level of ownership concentration in Germany.

4. Insiders are dominant shareholders in German companies, which is in line with Kaserer \& Moldenhauer (2007) and Erhardt, Nowak \& Weber (2005) results. At the same time, average ownership stakes of financial institutions and the government are low. This is due to the fact that financial institutions and the government either hold large (in most cases controlling stakes) in the companies, or have no holdings at all.

5. Correlation analysis does not yield any statistically significant results on the relationship between company performance and corporate governance variables. This is due to the fact that the relationship between the variables is distorted by other variables, observable (they would be included in regression analysis) and unobservable (they would be taken account of while ruling out endogeneity, e.g. by using instrumental variable method).

\section{Hypotheses and regression models}

The first set of hypotheses tested in this article is formulated in terms of ownership structure determinants. As demonstrated above in the overview of existing empirical research in the field of Выпуск \#4(12), 2009 
corporate governance and company performance, ownership structure should be treated as a vector of endogenous variables. Thus, the first step of any study of the links between ownership structures and company performance is to find the exogenous determinants of ownership.

Following Demsetz \& Villalonga (1985) and Ferreira \& Matos (2008), we test the impact of several factors on ownership structures. The specifics of the data used in the research allows us to add one more exogenous factor to ownership structures determinants: as the study is done on the data on German companies (2000-2006), for which substantial ownership reshuffling was the result of 2002 tax reform, the variable differentiating pre-reform and post-reform periods is also used as a factor in regressions. The resulting list of ownership structures determinants is the following:

1. Company size (Size);

2. Market risk, approximated by beta coefficient (beta);

3. Specific risk, approximated by standard error of the residual in the CAPM model (specrisk);

4. Dummy variable equaling one if the company is included in CDAX, which is the main German stock market index, and zero otherwise (Dummy_CDAX);

5. Dummy variable equaling one if the company has cross-listing in the US and zero otherwise (Dummy_US);

6. Dummy variable equaling one for the company-year observations after the tax reform (years 2002-2006) [Dummy_Post2001].

The general form of the model used in regression analysis is the following:

$$
O W N_{i t}=a+b_{1} \text { Size }_{i t}+b_{2} \text { specrisk }_{i t}+b_{3} \text { beta }_{i t}+b_{4}{\text { Dummy_Post } 2001_{i t}+\varepsilon_{i t},}
$$

where $O W N$ is one of the ownership concentration or ownership type variables described in more detail in the "Data description" section above, $\mathrm{i}$ is the individual company indicator and $\mathrm{t}$ is the period indicator. For institutional investors' ownership (Institutional), as done in Ferreira \& Matos (2008), we supplement the model with two additional factors and test it in the following form:

$$
\begin{aligned}
& \text { Institutio nal }_{i t}=a+b_{1} \text { Size }_{i t}+b_{2} \text { specrisk }_{i t}+b_{3} \text { beta }_{i t}+b_{4} \text { Dummy }_{-}{\text {Post } 2001_{i t}}+ \\
& +b_{5} \text { Dummy_CDAX }_{i t}+b_{6} \text { Dummy_US }_{i t}+\varepsilon_{i t}
\end{aligned}
$$

The hypotheses tested are summarized in the table below.

\begin{tabular}{|c|c|c|c|}
\hline & \multicolumn{3}{|c|}{ Dependent variable } \\
\hline Factors & $\begin{array}{c}\text { Ownership } \\
\text { concentration }\end{array}$ & $\begin{array}{l}\text { Ownership types (excluding } \\
\text { institutional investors) }\end{array}$ & Institutional investors ownership \\
\hline Size & \multicolumn{3}{|c|}{$\begin{array}{c}\mathbf{H}_{1}(\mathbf{A}) \text { : Negative. Investors face wealth constraints and seek diversification of their portfolios; as } \\
\text { a result, they choose to hold smaller stakes in larger companies. }\end{array}$} \\
\hline Specrisk & \multicolumn{3}{|c|}{$\begin{array}{l}\text { H}_{1} \text { (B): Negative or positive, depending on the balance of benefits and costs. High specific risk } \\
\text { gives large shareholders more control potential as they limit opportunistic actions of the } \\
\text { management; from the other side, in case investor holds large stake in the company, its non- } \\
\text { diversifiable risk may add substantial amount to the total risk of the investor's portfolio. }\end{array}$} \\
\hline Dummy_Post2001 & $\begin{array}{l}\mathbf{H}_{1}(\mathbf{C}) \text { : Negative. } \\
\text { Ownership } \\
\text { concentration } \\
\text { decreased as a } \\
\text { result of the } \\
\text { reform, and }\end{array}$ & \begin{tabular}{|}
$\mathbf{H}_{1}(\mathbf{D})$ : Negative for insiders \\
and financial institutions. As \\
these investor types became \\
exempt from capital gains \\
tax, they sold stakes in \\
companies which were held \\
since the foundation of the \\
company or its restructuring \\
[Weber (2009) and Fohlin \\
$(2005)]$.
\end{tabular} & $\begin{array}{l}\mathbf{H}_{2}(\mathbf{E}) \text { : Positive. As a result of tax reform, } \\
\text { institutional investors increased their holdings } \\
\text { in German companies buying stakes sold by } \\
\text { financial institutions (banks, pension funds) } \\
\text { and insiders (owner families, management). } \\
\text { This is in line with worldwide tendency } \\
\text { described e.g. by Bainbridge (2005). }\end{array}$ \\
\hline Dummy_CDAX & not tested & not tested & $\begin{array}{c}\mathbf{H}_{1}(\mathbf{F}) \text { : Positive. Institutional investors tend to } \\
\text { invest in companies from the country's main } \\
\text { stock market index, because they have high } \\
\text { liquidity and better disclosure, and many } \\
\text { institutional investors track stock indices in } \\
\text { their portfolios. }\end{array}$ \\
\hline
\end{tabular}

Table 4

Summary of the hypotheses regarding ownership structure determinants 


\begin{tabular}{|c|c|c|c|}
\hline Dummy_US & not tested & not tested & $\begin{array}{c}\mathbf{H}_{\mathbf{1}} \text { (G): Positive. As companies listed in the } \\
\text { US have higher disclosure standards and } \\
\text { follow "best practices" of corporate } \\
\text { governance, institutional investors tend to hold } \\
\text { stakes in them. }\end{array}$ \\
\hline
\end{tabular}

Note: (Negative/Positive in the cells indicates the sign of the relationship).

The second set and third sets of hypotheses are formulated with respect to the link between ownership structures and performance, and board characteristics and performance, respectively. The impact of ownership structure and board characteristics on company performance should be studied simultaneously, because they are jointly determined by exogenous and endogenous factors and may serve as substitutes or complements. For instance, low ownership concentration may be accompanied by high proportion of outside directors in the board: instead of holding large stakes and spending large resources for direct monitoring of management actions, shareholders may choose to nominate directors which guarantee their interests to the board.

In addition to corporate governance variables, we include in the regressions several control variables, which, as the study of existing empirical research indicated, may also impact performance and should therefore be taken into account in order to at least partially control for heterogeneity. These variables include company size, leverage, liquidity, profitability, company age, sales growth as well as industry dummy variables (for 14 industries in total). Detailed description of control variables was given in the "Data description" section.

For company performance we use two proxy variables employed in most of the prior studies: Tobin's Q and return on assets (ROA). These variables have certain drawbacks as proxies for performance which partially compensate one another. The value of Tobin's $Q$ is subject to stock market fluctuations; on the other side, ROA is the derivative of net income and thus can be easily manipulated, in addition, ROA does not take into account future performance of the company and its cash-generating ability and is therefore backward-looking.

General form of the model used for regression analysis is given below. This is so-called base regression model, estimated by ordinary least squares (OLS), which will be further modified in order to take into account unobserved heterogeneity and reverse causality.

$$
\begin{aligned}
& Q_{i t}=a+c_{0} O W N_{i t}+b_{1} \text { outside_directors }{ }_{i t}+b_{2} \text { size_sup ervisory_board }{ }_{i t}+ \\
& b_{3} \text { mandates_chairman }+b_{4} \text { chairman_former_executive }+X_{i t} \gamma+\sum_{k=1}^{14} c_{k} i^{i n d^{k}{ }_{i}+\varepsilon_{i t}},
\end{aligned}
$$

where $Q$ is Tobin's Q or one of its modifications (as explained in the "Data description" section), OWN is one of the ownership concentration characteristics or ownership types stakes, four variables included in the regression equation after it are board characteristics, $X_{\mathrm{it}}$ is the vector of control variables, and $i n d^{k}{ }_{i}$ is the dummy variable equalling one if the company $\mathrm{i}$ belongs to industry $\mathrm{k}$ and zero otherwise.

Tobin's Q in the equation (5) can also be substituted by ROA.

With respect to the link between corporate governance elements and company performance the following hypotheses are tested:

\section{Block 2 (Ownership structure and performance)}

$\mathrm{H}_{2}$ (main): Agency benefits of ownership concentration (in terms of lower management opportunism due to monitoring) exceed the costs of concentrated ownership (in the form of private benefits to the detriment of minority shareholders). Coefficient $\mathrm{c}_{0}$ is positive in regression with ownership concentration.

$\mathrm{H}_{2}$ (alternative): Agency costs of ownership concentration exceed the benefits, coefficient $\mathrm{c}_{0}$ is negative.

$\mathrm{H}_{3}$ (A): The presence of institutional investors among blockholders improve the performance of the company. Institutional investors are capable of monitoring the management; however, for them potential private benefits of control, for example, in the form of tunneling are virtually nonexistent. Coefficient $\mathrm{c}_{0}$ for institutional ownership variable is positive. 
$\mathrm{H}_{3}$ (B) [main]: Insider ownership has high agency costs as this type of investors is most capable of using private benefits of control (making deals at transfer prices with affiliated companies, investing in pet projects, etc.). Agency costs exceed the benefits, so coefficient $\mathrm{c}_{0}$ for insider ownership variable is negative.

$\mathrm{H}_{3}$ (B) [alternative]: The presence of insiders among blockholders results in higher company performance. Benefits from insider ownership, including not only the monitoring of the management, but also long-term strategic approach to business decision, exceed agency costs (Kaserer \& Moldenhauer 2007). Coefficient $\mathrm{c}_{0}$ for insider ownership variable is positive.

$\mathrm{H}_{3}(\mathrm{C})$ : Financial institutions, acting as blockholders, do not improve the performance of the company: coefficient $\mathrm{c}_{0}$ for financial institutions ownership is negative. As Weber (2009) notes, financial institutions usually accumulate stakes in German companies not in order to decrease the costs of management opportunism, but in the process of corporate restructuring.

$\mathrm{H}_{3}$ (D): The presence of government as a blockholder on average decreases performance, because government representatives and the management appointed by them do not have proper economic motivation for maximization of company value. Coefficient $\mathrm{c}_{0}$ for government ownership is negative

\section{Block 3 (Board characteristics and performance)}

$\mathrm{H}_{4}$ (A): The relationship between company performance and the share of outside directors in the board (outside_directors) is nonexistent or negative (coefficient $b_{1}$ in equation (5) is negative). According to Steger \& Steffen report (2008), the functions performed by supervisory board and outside directors within it cannot significantly impact company performance, because major actions are taken by management board. Negative relationship between the share of outside directors and company performance would thus be the evidence of signaling theory: as a result of poor company performance outside directors are appointed by the management or by controlling shareholders in order to improve performance using the professional competences of the directors and to send positive signal to investors (high share of outside directors in the board is viewed as part of "best corporate governance practices").

$\mathrm{H}_{4}$ (B): There is negative relationship between supervisory board size (size_supervisory_board) and company performance (Yermack 1996): coefficient $b_{2}$ is negative. If supervisory board becomes large, agency conflicts arise within it and different groups of interest are formed. As a result, overall company performance may be affected.

$\mathrm{H}_{4}(\mathrm{C})$ : There is negative relationship between company performance and the number of seats which the chairman of supervisory board holds in other companies' boards (mandates_chairman): coefficient $b_{3}$ is negative. As Fich \& Shivdasani (2006) demonstrated, "busy" directors are performing their supervisory functions less efficiently.

$\mathrm{H}_{4}$ (D): Company performance is lower if the supervisory board chairman is former executive (dummy variable chairman_former_executive equals one): coefficient $b_{4}$ is negative. If supervisory board chairman is affiliated with management, overall supervisory board is less efficient in pursuing the interests of shareholders.

\section{Empirical methodology}

Regression (4) is the starting point for analysis of the link between company performance and corporate governance elements; however, its results should be interpreted with caution due to the problems of endogeneity and reverse causality. More specifically, the establishment of causality between company performance and ownership structures requires more complicated econometrics techniques compared to OLS employed in equation (4).

The problem of endogeneity lies in the presence of unobserved factors which affect both ownership structures and performance. In particular, Himmelberg, Hubbard \& Palia (1999) identify three potential sources of endogeneity: the quality of monitoring technology available to company shareholders, market position of the firm and the uncertainty of the firm's business environment.

If shareholders of the firm have access to superior monitoring technology, the optimal level 
of ownership concentration would be lower; at the same time market capitalization and Tobin's Q would likely be high due to cost savings on monitoring. In the same way, if a company's market position allows the company to receive large profits compared to competitors, managers have substantial scope for opportunistic actions, so higher level of ownership concentration is optimal. The company's superior profitability would at the same time result in higher Tobin's Q. Finally, if the company's business environment is characterized by high level of uncertainty and large portion of the company's assets is comprised of intangibles, management has significant potential for opportunism. High ownership concentration would be followed by high Tobin's Q as the denominator of this coefficient does not take into account intangible assets.

The problem of endogeneity is described in econometric analysis terms below, following Himmelberg, Hubbard \& Palia (1999) study.

Assume that both Tobin's Q (the same line of reasoning could be used for an alternative performance measure, ROA) and ownership structure characteristics (OWN) are affected by a set of observable variables $\left(\mathrm{X}_{\mathrm{it}}\right)$, included in the regression, and by an unobserved characteristic $u$. Direct relationship between ownership structure variable and Tobin's $\mathrm{Q}$ is also present:

(5) Tobins $Q_{i t}=a_{1}+X_{i t} \beta_{1}+\gamma O W N_{i t}+\delta_{1} u_{i t}+v_{i t}$

(6) $O W N_{i t}=a_{2}+X_{i t} \beta_{2}+\delta_{2} u_{i t}+\mu_{i t}$

As $u$ is an unobserved characteristic, in practice the system of equations (5) and (6) is estimated in reduced form:

(7) Tobins $Q_{i t}=a_{1}+X_{i t} \beta_{1}+\gamma O W N_{i t}+\varepsilon_{i t}$

Coefficient $\gamma$ in the equation (7) cannot be estimated without bias under the ordinary least squares method, because one of the Gauss-Markov theorem conditions does not hold: one of the factors $(\mathrm{OWN})$ is correlated with the residual:

$$
\operatorname{Cov}\left(O W N_{i t}, \varepsilon_{i t}\right)=\operatorname{Cov}\left(\delta_{2} u_{i t}, \delta_{1} u_{i t}\right)=\delta_{1} \delta_{2} \sigma^{2}{ }_{u} \neq 0
$$

The reverse causality problem, described in the works of Gianetti \& Laeven (2008) and Becker, Cronquist \& Fahlenbrach (2008), lies in the fact that the relationship between ownership structure elements and performance may work both ways. In particular, if existing shareholders have insider information about future company performance improvement (which is most likely is these shareholders are at the same time performing management functions), they may increase their ownership stakes in advance in order to capture more benefits from company's value growth.

In order to cope with endogeneity and reverse causality problems, three approaches were employed in this article: fixed effects panel data regression [Himmelberg, Hubbard and Palia (1999), Gianetti and Laeven (2008)], instrumental variables model [Becker, Cronquist and Fahlenbrach (2008), Gianetti and Laeven (2008), Ferreira and Matos (2007)] and the system of simultaneous equations [Ferreira and Matos (2007)]. We further describe instrumental variables and simultaneous equations approaches in more details, because the results of these approaches form the basis for main conclusions of this article.

In the instrumental variables method the problem of ownership structure endogeneity is solved by substituting the ownership characteristic variable (OWN) from equation (8) for its estimate obtained by running the supplementary regression of ownership characteristics variable on the number of exogenous factors (instruments):

$$
O W N_{i t}=a_{2}+X_{i t} \beta_{2}+\sum_{k=1}^{K} \theta I V^{k}{ }_{i t}+\mu_{i t}
$$

, where $\mathrm{IV}_{\mathrm{it}}$ is the vector of instrumental variables.

The estimate of ownership structure characteristics variable from equation (9) can further be used as explanatory variable for Tobin's Q:

(10) Tobins $Q_{i t}=a_{1}+X_{i t} \beta_{1}+\gamma O W N^{*}{ }_{i t}+\varepsilon_{i t}$

The system of equations (9) and (10) can be estimated by the maximum likelihood method (MML) or by the two-stage least squares (2SLS) method.

The authors of existing empirical literature in the field of corporate governance use for 
ownership structure characteristics such instrumental variables as company size and the level of uncertainty (Demsetz \& Lehn 1985, Demsetz \& Villalonga 2001), company age (Erhardt, Nowak \& Weber 2006), dummy variables for cross-listing and inclusion in the major stock market index (Ferreira \& Matos 2008), and certain corporate governance characteristics (in particular, the percentage of non-voting shares in the company's shares capital).

In this article we use ownership structure determinants, identified when testing the first set of hypotheses, as instrumental variables. As a result, instruments for ownership concentration and all ownership types include specific risk (residual in the CAPM model) and dummy variable for the period after the tax reform. In addition, for institutional investors ownership dummy for the inclusion of the company in the CDAX index and the cross-liting dummy are used as instruments. As a result, the system of regressions being estimated has the following form (an example is given for institutional investors' ownership as the factor, in similar regressions it is substituted for other ownership structure characteristics; in addition, in the alternative specification Tobin's Q in the second-stage regression is substituted for ROA):

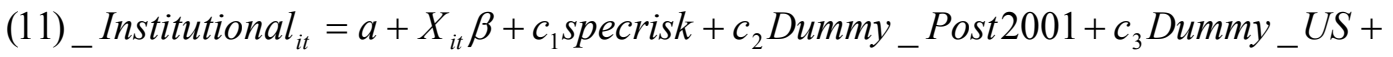
$+c_{4}$ Dummy_CDAX+ $\varepsilon_{i t}$

(12)_ $Q_{i t}=d_{0}+d_{1}$ Institutional $+X_{i t} \phi+\mu_{i t}$

The system of simultaneous equations is essentially a modification of instrumental variables method. Within this approach the system of two regressions of two key variables (in this article they are one of the performance measures and one of ownership structure characteristics) on each other and on a set of control variables are constructed. For the identification of causal relationships between the key variables a set of exogenous variables is used. In this article they are the same as for the instrumental variables method. The system of simultaneous equations for the testing of the link between performance (Tobin's Q) and institutional investors' ownership is presented below.

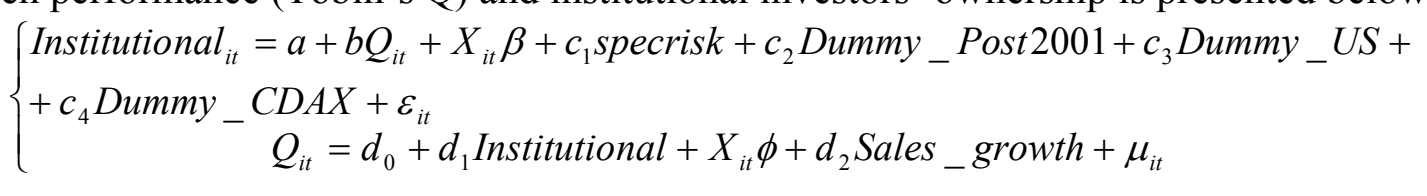

\section{Empirical research results}

The table below presents the results of OLS regressions of different ownership structure characteristics on the number of factors, which were described in Section 4. For each ownership structure characteristics a regression of the form (2) was estimated, and for institutional investors' ownership (variable Institutional) dummy variables for the company's membership in the CDAX index and for cross-listing in the US were included as factors (equation (3)). All regression analysis was conducted in Stata, and regression standard errors were adjusted for autocorrelation and heteroscedasticity. As for three ownership concentration measures (block_ownership, top_blockholder, ownership_concentration) regression results were similar, they are shown in the same column with the heading "Ownership concentration". 
Results of the ownership structures determinants testing (first set of hypotheses)

\begin{tabular}{|l|c|c|c|c|c|}
\hline \multirow{2}{*}{ Factors } & \multicolumn{5}{c|}{ Dependent variables } \\
& $\begin{array}{c}\text { Ownership } \\
\text { concentration }\end{array}$ & Insider & Financials & Government & Institutional \\
\hline Size & $\mathrm{n} / \mathrm{s}$ & - & + & + & - \\
\hline Specrisk & - & + & + & $\mathrm{n} / \mathrm{s}$ & - \\
\hline Beta & $\mathrm{n} / \mathrm{s}$ & $\mathrm{n} / \mathrm{s}$ & $\mathrm{n} / \mathrm{s}$ & $\mathrm{n} / \mathrm{s}$ & $\mathrm{n} / \mathrm{s}$ \\
\hline Dummy_Post2001 & - & - & - & $\mathrm{n} / \mathrm{s}$ & + \\
\hline Dummy_CDAX & \multicolumn{5}{|c|}{ not tested } \\
\hline Dummy_US & \multicolumn{7}{|c|}{ not tested } \\
\hline \multicolumn{2}{|c|}{ Note: + - denotes positive/negative significant relationship, n/s denotes no statistically significant relationship }
\end{tabular}

We observe that ownership concentration is not directly linked to the company size, because financial institutions and the government hold stakes in larger companies, whereas smaller companies have insiders and institutional investors among blockholders. Specific risk (standard deviation of the residual in the CAPM model) on average is associated with lower ownership concentration; however, insider and financial institutions ownership is higher in the companies with high specific risk. For financial institutions this may be explained by the fact that in Germany banks often acquire stakes in distressed companies, characterized by high specific risk; for insiders it implies that this type of investors acquires large stakes in the companies where the management has substantial potential for opportunism, and utilizes the control potential by monitoring the management and thus decreasing the agency costs. Beta (market risk) does not affect ownership structures (the same result was observed by Demsetz \& Lehn (1985) and Demsetz \& Villalonga (2001)).

As a result of tax reform, which became effective on January 1, 2002, overall level of ownership concentration in German corporations decreased, so the country's corporate governance system became closer to those of Anglo-Saxon countries. This was accompanied by the redistribution of ownership stakes among different ownership types: insiders and financial institutions decreased their holdings, and institutional investors' ownership increased. Two other factors, the company's presence in the main German stock market index and cross-listing in the US, determine higher institutional investors' ownership.

The analysis described above allowed us to identify several external factors which may be used as instruments for ownership structures characteristics in order to solve endogeneity and reverse causality problems when studying the link between ownership structure and performance.

Tables 6 and 7 below present the results of the regressions of corporate performance on corporate governance variables and the set of controls (equation (4) for OLS estimation, equations (11) and (12) for instrumental variables estimation). Although second and third set of hypotheses (relationship between ownership structure characteristics and board characteristics, on the first side, and corporate performance, on the other side) were at the first stage tested using OLS, the regression results were inconclusive. In Table 6 we therefore present the results of instrumental variables estimation, which allowed us to establish causal links between ownership structures and performance. However, it should be noted that for board characteristics it was not possible to use instrumental variables, so the direction of the relationship between these variables and corporate performance cannot be identified with certainty. However, we used fixed effects estimation in order to rule out the possible impact of time-invariant unobserved factors on the relationship between board characteristics and performance, following Himmelberg, Hubbard \& Palia (1999). 
Results of the testing of the relationship between company performance (second and third set of hypotheses)

\begin{tabular}{|c|c|c|c|c|}
\hline & \multicolumn{4}{|c|}{ Corporate governance variables used as explanatory variables in regression } \\
\hline & \multicolumn{4}{|c|}{ Ownership concentration } \\
\hline Tobin's $Q / R O A$ & \multicolumn{4}{|c|}{$\begin{array}{l}\text { No relationship. The direction of the impact of different owner types on } \\
\text { performance is different. Hypothesis } \mathrm{H}_{2} \text { is rejected. }\end{array}$} \\
\hline & Financials & Institutional & Insider & Government \\
\hline Tobin's $Q / R O A$ & $\begin{array}{c}\text { Negative relationship. } \\
\text { Hypothesis } \mathrm{H}_{3}(\mathrm{C}) \text { is } \\
\text { not rejected. }\end{array}$ & $\begin{array}{c}\text { Positive } \\
\text { relationship. } \\
\text { Hypothesis } \\
\mathrm{H}_{3}(\mathrm{~A}) \text { is not } \\
\text { rejected. }\end{array}$ & $\begin{array}{c}\text { Negative } \\
\text { relationship. } \\
\text { Hypothesis } \\
\mathrm{H}_{3}(\mathrm{~A}) \text { [main] is } \\
\text { not rejected. }\end{array}$ & $\begin{array}{c}\text { Positive } \\
\text { relationship for } \\
\text { ROA. } \\
\text { Hypothesis } \\
\mathrm{H}_{3}(\mathrm{D}) \text { is } \\
\text { rejected. }\end{array}$ \\
\hline & $\begin{array}{l}\text { Supervisory board } \\
\text { size }\end{array}$ & $\begin{array}{c}\text { Percentage of } \\
\text { outside } \\
\text { directors }\end{array}$ & $\begin{array}{l}\text { Other mandates } \\
\text { of the chairman }\end{array}$ & $\begin{array}{l}\text { Chairman is } \\
\text { former } \\
\text { executive }\end{array}$ \\
\hline Tobin's $Q / R O A$ & $\begin{array}{c}\text { Negative relationship. } \\
\text { Hypothesis } \mathrm{H}_{4}(\mathrm{~B}) \text { is } \\
\text { not rejected. }\end{array}$ & $\begin{array}{l}\text { Negative } \\
\text { relationship. } \\
\text { Hypothesis } \\
\mathrm{H}_{4}(\mathrm{~A}) \text { is not } \\
\text { rejected. }\end{array}$ & $\begin{array}{c}\text { No consistent } \\
\text { relationship. } \\
\text { Hypothesis } \\
\mathrm{H}_{4}(\mathrm{C}) \text { is } \\
\text { rejected. }\end{array}$ & $\begin{array}{l}\text { No consistent } \\
\text { relationship. } \\
\text { Hypothesis } \\
\mathrm{H}_{4}(\mathrm{C}) \text { is } \mathrm{r} \\
\text { ejected. }\end{array}$ \\
\hline
\end{tabular}

Notes:

1 - “+”/”“" denotes positive/negative significant relationship, $n / s$ denotes no statistically significant relationship

2 - The tables presents instrumental variables estimation results. The results obtained under the simultaneous equations method are qualitatively the same, so they are not reported.

Relationship between corporate performance (Tobin's Q) and control variables

\begin{tabular}{|c|c|c|}
\hline Factor & $\begin{array}{l}\text { Sign of the } \\
\text { relationship }\end{array}$ & Interpretation \\
\hline Age & Negative & $\begin{array}{l}\text { During the company's life cycle its growth potential and, as a } \\
\text { result, Tobin's Q decreases, also due to the intensification of } \\
\text { agency conflicts as corporate structure becomes more complex. }\end{array}$ \\
\hline Sales growth & Positive & $\begin{array}{l}\text { Last year growth rate is on average correlated with future growth } \\
\text { rates, which directly affect Tobin's Q }\end{array}$ \\
\hline Liquidity & Positive & $\begin{array}{l}\text { Liquidity, which is the ratio of cash \& marketable securities to } \\
\text { total assets, is lower for capital-intensive industries, which are } \\
\text { characterized by high Tobin's Q }\end{array}$ \\
\hline Profitability & Positive & $\begin{array}{l}\text { Historical profitability is on average correlated with future } \\
\text { profitability, which directly affects Tobin's Q }\end{array}$ \\
\hline Leverage & $\begin{array}{c}\text { Not } \\
\text { significant }\end{array}$ & \\
\hline
\end{tabular}

\section{Discussion and conclusion}

The purpose of this article was the development of adequate empirical methodology for the study of relationship between endogenous corporate governance elements (ownership structure and board characteristics) and performance and testing of this methodology for the market with concentrated ownership. Based on the analysis of existing empirical research in the field, we came to the conclusion that instrumental variables and simultaneous equations techniques are the most 
relevant methodology to deal with endogeneity and reverse causality potentially present in the relationship between company performance and ownership structure characteristics.

This methodology was tested on the data from the developed market with concentrated ownership (Germany). High quality of the data available and large number of observations ensure the robustness of the results, and similarity of corporate governance system of this country to corporate governance systems in emerging markets makes main conclusions of the research potentially relevant for emerging markets as well. In addition, the tax reform, which became effective in Germany in 2002, resulted in the reshuffling of ownership structures and created time variance in the data which makes the results more statistically significant.

At the first stage of the empirical research we determined the exogenous factors affecting ownership structures. At the second stages these factors were used as instruments in instrumental variables and simultaneous equation methods in order to identify causal links between ownership structures and company performance. Board characteristics were also included in the regressions at second stage. The main conclusions of the empirical research, conducted in this article, are summarized below.

First, in corporate governance systems with high ownership concentration it is necessary to study ownership structure as a vector of variables, not as a single indicator e.g. the sum of all blockholders' stakes. The presence of different ownership types may have specific impact on company performance, so the level of ownership concentration itself may not be associated with systematically higher or lower performance.

Second, insider ownership in concentrated ownership systems like German one creates more agency costs than benefits. As this research demonstrated, insider ownership is high in small companies with high specific risk: the first factor allows insiders who as individuals have certain wealth constraints to accumulate large stakes, the second creates control potential for monitoring the management. Although certain value-enhancing effect from limiting management opportunism may exist, the dominant impact of insider ownership on performance is negative, thus suggesting high private benefits of control (tunneling, transfer pricing, investments in pet projects etc.).

Third, the presence of institutional investors among blockholders enhances the performance of companies. This positive effect stems from the use of indirect mechanisms such as board representation, strategy discussions with the company's management proxy contests and the threat of exit from the company's capital, rather than from direct monitoring of the management. As the testing of ownership types determinants indicated, institutional investors avoid companies with high specific risk and high control potential and instead prefer the companies included in the country's main stock market index and cross-listed in one of the major world stock exchanges.

The cross-listing factor seems to be especially important in the context of concentrated ownership systems, especially in the emerging markets. Countries with such governance systems a priori have relatively small stock markets; however, the companies operating there have an opportunity to improve their performance by achieving cross-listing in one of the world major stock exchanges (London or New York) and thus encouraging institutional investors to become their shareholders. Any policy measures prohibiting or limiting cross-listing, such as ones currently effective in Russia, hinder companies' corporate governance systems improvement and are eventually value-destroying.

In addition, it was shown that the view of equilibrium ownership structure and "ownership structure and performance neutrality", argued for by Demsetz \& Lehn (1985), is not supported for the countries where ownership concentration is high and transaction costs of ownership structure changes are substantial. Until capital gains tax was abolished in Germany in 2002, suboptimal ownership structures with high insider ownership and low institutional investors ownership were predominant, and after the tax reform reshuffling of ownership structures took place. Therefore, governments should exercise caution when introducing any policies which may create high ownership structures changes costs.

The findings of this research with respect to the impact of board characteristics on company performance support prior studies (Hermalin \& Weisbach 2003): companies with smaller boards 
perform better, and higher portion of outside directors in supervisory board is associated with lower performance. In the light of the empirical literature studied, here it is important to differentiate between causes and consequences. Although it is possible that outside directors negatively impact the performance of companies due to lack of competence and motivation, more obvious is the conclusion that German companies tend to invite outside directors to their supervisory boards in case of bad performance, in order to give positive signal to investors. The proof of causality in this relationship, however, requires the situation of "natural experiment" to be present, like the one in Korea in 1999 (Black \& Kim 2008).

The methodology developed in this article and the results obtained provide large scope for further research. First, upon obtaining panel data on companies from emerging markets the same research methodology can be used, since it allows for differentiating between owner types and separating the effect of insider ownership on performance, which is especially important for emerging markets. Second, the interaction between different owner types in the same company may be studied: for this purpose, the variable representing the product of two owner-type variables (e.g. insiders and institutional investors) should be added to explanatory variables. Third, more detailed study of different ownership types may be conducted: in particular, institutional investors may be separated into pension funds, mutual funds, hedge funds and private equity funds, and insiders can be differentiated into managers, board members and family owners. Fourth, as ownership structures evolve over the company life cycle, companies in the sample may be separated into several groups depending on age and separate regressions may be run. Finally, in order to establish causal links between board characteristics and company performance the "natural experiment" setting (board characteristics changes due to policy measures) should be found. Given that governments all over the world are now considering the possibilities of changing company law in order to respond to corporate governance challenges which emerged as a result of financial crisis, such "natural experiments" may emerge in the near future.

\section{References}

1. Bainbridge, S. (2005), Shareholder Activism and Institutional Investors, UCLA School of Law, Law-Econ Research Paper No. 05-20

2. Becker, B., Cronqvist, H., Fahlenbrach, R. (2009), Estimating the effects of large shareholders using a geographic instrument, Available at SSRN http://ssrn.com/abstract $=1101012$

3. Bhagat S., Black, B. (2008), The Non-Correlation between Board Independence and LongTerm Firm Performance, Journal of Corporate Law, 27 (2008) 231-274

4. Black, B., Jang, H., Kim, W. (2006), Does Corporate Governance Affect Firms' Market Values? Evidence from Korea, Journal of Law, Economics and Organization, 22 (2006) 366-413

5. Choi, J., Park, S., Yoo, S. (2007), The Value of Outside Directors: Evidence from Corporate Governance Reform from Korea, Journal of Financial and Quantitative Analysis, 42 (2007) 941- 962

6. Dahya, J., Dimitrov, O., McConnell, J. (2007), Dominant Shareholders, Corporate Boards, and Corporate Value: A Cross-Country Analysis, Journal of Financial Economics, 42 (2007) 535-564

7. Dahya, J., McConnell, J. (2007), Board Composition, Corporate Performance, and the Cadbury Committee Recommendation, Available at SSRN http://ssrn.com/abstract $=687429$

8. Demsetz, H., Lehn, K. (1985), The Structure of Corporate Ownership: Causes and Consequences, Journal of Political Economy, 93 (1985) 1155-1177

9. Demsetz, H., Villalonga, B. (2001), Ownership Structure and Corporate Performance, Journal of Corporate Finance, 7 (2001) 209-233

10. Driffield, N., Mahambare, V., Pal, S. (2006), How Does Ownership Structure Affect Capital 
Structure and Firm Performance? Recent Evidence from East Asia, Available at SSRN.

11. Earle, J. (1998), Post-Privatization Ownership Structure and Productivity in Russian Industrial Enterprises, Stockholm University of Transitional Economics, Working Paper No. 127

12. Ehrhardt, O., Nowak, E., Weber, F. (2006), Running in the family - The evolution of ownership, control, and performance in German family-owned firms 1903-2003, Swiss Finance Institute Research Paper No. 06-13.

13. Eisenberg, T., Sundgren, S., Wells, M. (1998), Larger board size and decreasing firm value in small firms, Journal of Financial Economics, 48 (1998) 35-54

14. Ferreira, M., Matos, P. (2008), The colors of investors' money: The role of institutional investors around the world, Journal of Financial Economics, 88 (2008), 499-533

15. Fohlin, C. (2005), The History of Corporate Ownership and Control in Germany, in: Morck, R. (eds.). A History of Corporate Governance around the World. Chicago and London, The University of Chicago Press, p. 223-277

16. Franks, J., Mayer, C. (2001), Ownership and control of German corporations, Review of Financial Studies, 14 (2001) 943-977

17. Giannetti, Mariassunta and Luc Laeven (2009), Pension reform, ownership structure, and corporate governance: Evidence from a Natural Experiment, Review of Financial Studies, 22 (2009) 4091-4127

18. Guriev S., Lazareva O., Rachinsky A., Tsouhlo S. (2003), Concentrated ownership, market for corporate control, and corporate governance, CEFIR Project, 2003, p. 23

19. Hermalin, B., Weisbach, M. (1991), The Effects of Board Composition and Direct Incentives on Firm Performance, Financial Management, Financial Management Association 20(4), Winter

20. Hermalin, B., Weisbach, M. (2003), Board of Directors as an Endogenously Determined Institution: A Survey of the Economic Literature, Economic Policy Review, 9 (2003) 7-26

21. Himmelberg, C., Hubbard, R., Palia, D. (1999), Understanding the determinants of managerial ownership and the link between ownership and performance, Journal of Financial Economics, 53 (1999) 353-384

22. Holderness, C. (2008), The Myth of Diffuse Ownership in the United States, Review of Financial Studies, 22 (2008) 1377-1408

23. Ivashkovskaya, I. \& A. Stepanova. Does Corporate Performance Depend on Corporate Financial Architecture? Empirical Study of European, Russian and Other Emerging Market's Firms. Presentation on the $5^{\text {th }}$ Corporate Governance Workshop, EIASM, November 27, 2008

24. Kaserer, C., Moldenhauer, B. (2007), Insider Ownership and Corporate Performance Evidence from Germany, CEFS Working Papier Series, No. 1/2005

25. Klein, A. (1998), Firm performance and board committee structure, Journal of Law and Economics, 41 (1998) 275-299

26. Kocenda, E., Svejnar, J. (2003), Ownership and Firm Performance after Large-Scale Privatization, CERGE-EI Working Papers wp209, The Center for Economic Research and Graduate Education - Economic Institute, Prague

27. Lins, K. (2003), Equity ownership and firm value in emerging markets, Journal of Financial and Quantitative Analysis, 38 (2003) 159-184

28. MacAvoy, P., Cantor, S., Dana, J., Peck, S. (1983), ALI proposals for increased control of the corporation by the board of directors: An economic analysis, Principles of Corporate Governance and Structure: Restatement and Recommendation, New York: Business Roundtable

29. McConnell, J., Servaes, H. (1990), Additional evidence on equity ownership and corporate value, Journal of Financial Economics, 27 (1990) 595-612

30. Mehran, H. (1995), Executive compensation structure, ownership and firm performance, Journal of Financial Economics, 38 (1995) 163-184 
31. Morck R., Shleifer A., Vishny R. (1998), Management ownership and market valuation: an empirical analysis, Journal of Financial Economics, 20 (1998) 293-315

32. Muravyev, A. (2002), Federal state shareholdings in Russian companies: Origin, forms and consequences for enterprise performance, BOFIT Discussion Papers, No. 122002

33. Rosenstein, S., Wyatt, J. (1990), Outside Directors, Board Independence, and Shareholder Wealth, Journal of Financial Economics, 26 (1990) 175-184

34. Rosenstein, S., Wyatt, J. (1997), Inside Directors, Board Effectiveness, and Shareholder Wealth, Journal of Financial Economics, 44 (1997) 229-248

35. Sautner, Z., Villalonga, B. (2009), Corporate Governance and Internal Capital Markets. Unpublished paper.

36. Thomsen, S. (2004), Blockholder Ownership, Dividends and Firm Value in Continental Europe, http://www.isnie.org/ISNIE04/Papers/thomsen.pdf

37. Villalonga, B., Amit, R. (2006), How Do Family Ownership, Control and Management Affect Firm Value? Journal of Financial Economics, 80 (2006) 385-417

38. Weber, A. (2009), An Empirical Analysis of the 2000 Corporate Tax Reform in Germany: Effects on Ownership and Control in Listed Companies, International Review of Law and Economics, 29 (2009) 57-66

39. Yermack, D. (1996), Higher Market Valuation of Companies with a Small Board of Directors, Journal of Financial Economics, 40 (1996) 185-211

40. Yin-Hua, Y., Woidtke, T. (2005), Commitment or Entrenchment? Controlling Shareholders and Board Composition, Journal of Banking and Finance, 29 (2005) 1857-1885

41. Боков В.А., Верников А.В. Качество корпоративного управления и стоимость банков в России: эмпирическое исследование // Электронный журнал ГУ-ВШЭ «Корпоративные финансы» - 2008 - №3 - С. 5-16

42. Долгопятова Т.Г. Собственность и корпоративный контроль в российских компаниях в условиях активизации интеграционных процессов // Российский журнал менеджмента. - 2004. - Т. 2. № 2. - С. 3-26

43. Ивашковская И.В., Степанова А.Н. Структура собственности как элемент корпоративной финансовой архитектуры: влияние на стратегическую эффективность компаний // Финансы и бизнес. - 2009 - №3

44. Кузнецов П.В., Муравьев А.А. Структура акционерного капитала и результаты деятельности фирм в России (анализ «голубых фишек» фондового рынка) // Экономический журнал Высшей школы экономики - 2000 - №4 - С. 475-504

45. Пирогов Н.К., Бобрышев Н.А. Взаимосвязь агентских издержек и структуры собственности на примере российских и восточноевропейских компаний // Электронный журнал ГУ-ВШЭ «Корпоративные финансы» - 2009 - №10 - С. 40-56

46. Радыгин А.Д., Энтов Р.М. Корпоративное управление и защита прав собственности: эмпирический анализ и актуальные направления реформ. М., 2001

\section{Appendix}

Table A1.

Descriptive statistics for performance characteristics and control variables

\begin{tabular}{|l|c|c|c|c|}
\hline \multicolumn{1}{|c|}{ Variable } & Average & Median & $\begin{array}{c}\text { Standard } \\
\text { deviation }\end{array}$ & $\begin{array}{c}\text { Number of } \\
\text { observations }\end{array}$ \\
\hline $\begin{array}{l}\text { Market } \\
\text { capitalization, } \\
\text { th EUR }\end{array}$ & $2,172,443$ & 84,472 & $8,014,638$ & 1,910 \\
\hline $\begin{array}{l}\text { Book value of } \\
\text { total assets, } \text { th } \\
\text { EUR }\end{array}$ & $4,858,696$ & 128,477 & $21,400,000$ & 1,916 \\
\hline Tobin's $Q$ & 1.571 & 1.227 & 1.127 & 1,877 \\
\hline
\end{tabular}




\begin{tabular}{|l|c|c|c|c|}
\hline \multicolumn{1}{|c|}{ Variable } & Average & Median & $\begin{array}{c}\text { Standard } \\
\text { deviation }\end{array}$ & $\begin{array}{c}\text { Number of } \\
\text { observations }\end{array}$ \\
\hline ROA & $1.7 \%$ & $5.8 \%$ & $36.0 \%$ & 1,790 \\
\hline Leverage & $35.12 \%$ & $25.16 \%$ & $140.27 \%$ & 1,915 \\
\hline Liquidity & 0.17 & 0.08 & 0.39 & 1,314 \\
\hline Firm age, years & 45 & 21 & 50 & 1,669 \\
\hline
\end{tabular}

Table A2.

Descriptive statistics for ownership structure characteristics

\begin{tabular}{|l|c|c|c|c|}
\hline \multicolumn{1}{|c|}{ Variable } & Average & Median & $\begin{array}{c}\text { Standard } \\
\text { deviation }\end{array}$ & $\begin{array}{c}\text { Number of } \\
\text { observations }\end{array}$ \\
\hline Block_ownerhsip & $41.0 \%$ & $44.7 \%$ & $26.1 \%$ & 1765 \\
\hline $\begin{array}{l}\text { Ownership } \\
\text { concentration }\end{array}$ & 0.1665 & 0.1056 & 0.1729 & 1765 \\
\hline Top_blockholder & $31.5 \%$ & $27.1 \%$ & $23.1 \%$ & 1765 \\
\hline Financials & $1.9 \%$ & $0.0 \%$ & $6.7 \%$ & 1765 \\
\hline Institutional & $4.6 \%$ & $0.0 \%$ & $13.4 \%$ & 1765 \\
\hline Government & $1.0 \%$ & $0.0 \%$ & $6.8 \%$ & 1765 \\
\hline Insider & $22.8 \%$ & $13.6 \%$ & $24.8 \%$ & 1765 \\
\hline
\end{tabular}

Table A3.

Descriptive statistics for board characteristics

\begin{tabular}{|l|l|l|l|l|l|l|}
\hline \multicolumn{1}{|c|}{ Variable } & Average & Median & $\begin{array}{l}\text { Standard } \\
\text { deviation }\end{array}$ & Minimum & Maximum & $\begin{array}{c}\text { Number of } \\
\text { observations }\end{array}$ \\
\hline $\begin{array}{l}\text { Supervisory } \\
\text { board size }\end{array}$ & 7.6 & 6.0 & 5.4 & 1 & 24 & 1748 \\
\hline $\begin{array}{l}\text { Executive board } \\
\text { size }\end{array}$ & 3.4 & 3.0 & 1.6 & 1 & 13 & 1745 \\
\hline $\begin{array}{l}\text { Percentage of } \\
\text { outside directors } \\
\text { in the } \\
\text { supervisory } \\
\text { board }\end{array}$ & $80.2 \%$ & $100.0 \%$ & $23.6 \%$ & $0.0 \%$ & $100.0 \%$ & 1748 \\
\hline $\begin{array}{l}\text { Percentage of } \\
\text { outside directors } \\
\text { in the } \\
\text { supervisory } \\
\text { board and } \\
\text { executive board }\end{array}$ & $50.7 \%$ & $50.0 \%$ & $13.8 \%$ & $0.0 \%$ & $92.3 \%$ & 1741 \\
\hline $\begin{array}{l}\text { Mandates of the } \\
\text { chairman }\end{array}$ & 2.91 & 2.00 & 2.87 & 0.00 & 19.00 & 1724 \\
\hline $\begin{array}{l}\text { Chairman is } \\
\text { former executive } \\
\text { (dummy) }\end{array}$ & $12 \%$ & & & & 1732 \\
\hline
\end{tabular}


Correlation analysis

Panel A: Tobin's Q and ownership structure characteristics

\begin{tabular}{|l|c|c|c|c|c|c|c|c|}
\hline & $\begin{array}{c}\text { Tobin's } \\
Q\end{array}$ & $\begin{array}{c}\text { block } \\
\text { ownership }\end{array}$ & $\begin{array}{c}\text { ownership } \\
\text { concentration }\end{array}$ & $\begin{array}{c}\text { top } \\
\text { blockho } \\
\text { lder }\end{array}$ & $\begin{array}{c}\text { Instituti } \\
\text { onal }\end{array}$ & Insider & $\begin{array}{c}\text { Govern } \\
\text { ment }\end{array}$ & Financial \\
\hline Tobin's $Q$ & 1.0000 & & & & & & & \\
\hline $\begin{array}{l}\text { block } \\
\text { ownership }\end{array}$ & -0.0015 & 1.0000 & & & & & & \\
\hline $\begin{array}{l}\text { ownership } \\
\text { concentratio } \\
n\end{array}$ & 0.0449 & 0.8331 & 1.0000 & & & & & \\
\hline $\begin{array}{l}\text { top } \\
\text { blockholder }\end{array}$ & 0.0408 & 0.8668 & 0.9583 & 1.0000 & & & & \\
\hline Institutional & -0.0279 & 0.2366 & 0.1991 & 0.1784 & 1.0000 & & & \\
\hline Insider & -0.0037 & 0.5300 & 0.3877 & 0.4626 & -0.1878 & 1.0000 & & \\
\hline Government & -0.0594 & 0.0550 & 0.0593 & 0.0639 & -0.0535 & -0.1381 & 1.0000 & \\
\hline Financial & -0.0625 & 0.0686 & -0.0183 & -0.0058 & -0.0743 & -0.1369 & 0.0093 & 1.0000 \\
\hline
\end{tabular}

Panel B: Tobin's Q and board characteristics

\begin{tabular}{|l|c|c|c|c|c|c|}
\hline & Tobin's Q & $\begin{array}{c}\text { Supervisory } \\
\text { board size }\end{array}$ & $\begin{array}{c}\text { Executive } \\
\text { board size }\end{array}$ & $\begin{array}{c}\text { Percentage } \\
\text { of outside } \\
\text { directors }\end{array}$ & $\begin{array}{c}\text { Mandates } \\
\text { of the } \\
\text { chairman }\end{array}$ & $\begin{array}{c}\text { Chairman } \\
\text { is former } \\
\text { executive }\end{array}$ \\
\hline Tobin's $Q$ & 1.0000 & & & & & \\
\hline $\begin{array}{l}\text { Supervisory } \\
\text { board size }\end{array}$ & -0.0936 & 1.0000 & & & & \\
\hline $\begin{array}{l}\text { Executive } \\
\text { board size }\end{array}$ & 0.0077 & 0.6464 & 1.0000 & & \\
\hline $\begin{array}{l}\text { Percentage } \\
\text { of outside } \\
\text { directors }\end{array}$ & 0.0099 & -0.8018 & -0.5026 & 1.0000 & & \\
\hline $\begin{array}{l}\text { Mandates } \\
\text { of the } \\
\text { chairman }\end{array}$ & 0.0055 & 0.2740 & 0.2171 & -0.2326 & 1.0000 & \\
\hline $\begin{array}{l}\text { Chairman } \\
\text { is former } \\
\text { executive }\end{array}$ & -0.0230 & 0.0745 & 0.0879 & -0.1822 & -0.1251 & 1.0000 \\
\hline
\end{tabular}

